\title{
Educative value in Ta Sapta Jantraning Urip Sanggar Pasinaon Pambiwara Karaton Surakarta as Nation Character Builders
}

\author{
Sidhiq Hidayatulloh ${ }^{1}$, Sahid Teguh Widodo ${ }^{2}$, Kundharu Saddhono ${ }^{3}$
}

\author{
${ }^{1}$ Magister of Javanese Language Education Sebelas Maret University, Indonesia \\ ${ }^{2,3}$ Lecture in Javanese Language Education Sebelas Maret University, Indonesia
}

\begin{abstract}
This study describes the educational value in ta sapta jantraning urip which is taught in the Sanggar Pasinaon Pambiwara Karaton Surakarta, the analysis of social practices and educational valuesin the Javanese Life Ceremony is discussed using the term TA SAPTA JANTRANING URIP (Seven TA of life journeys) which consists of Titis, Titah, Tetes, Tarab, Tatap, Tutug, dan Tutup. Through this research, it is hoped that readers will be able to know and apply good moral teachings that can be applied around Javanese traditional ceremonies and ceremonies along with the development of the times.The urgency of the research is that the results of this research become a referenceand guideline for relevant research and as a consideration for one form of Strengthening Character Education. The purpose of this research is to describe the educational values contained in Ta Sapta Jantraning Urip as a character builder of the nation.This study used descriptive qualitative method.The data of this research were taken from the document in the form of writing about the Ta Sapta Jantraning Urip belonging to the Sanggar Pasinaon Pambiwara Karaton Surakarta Hadiningrat.
\end{abstract}

Keywords- Educational value, Ta Sapta Jantraning Urip, Nation Character Builder, Javanese Traditional Ceremony.

\section{INTRODUCTION}

Education is a necessity for humans because basically humans are born helpless. God has given human potentials to be explored, utilized, and developed in order to become a quality human being so as to create a dignified future generation. Education is understood as a process of cultural internalization into a person and society so that it makes people and society adapt (Muslich, 2011: 75). In addition, Syahidin argued that education as a social institution has a function as a social change process that is able to accommodate the social character of society, which is not just a transfer of information about knowledge from educators to students, but a character building process that has three main missions. namely, the inheritance of knowledge (transfer of knowledge), cultural inheritance (transfer of culture), and inheritance of value (transfer of value). Therefore, education is understood as a process of transforming values in order to form individual personalities (Nugroho, 2016: 33). However, what is happening in education in the current era is really concerning, there are many cases of violence, bullying, cheating, and even immoral acts that are considered normal.

In this connection, character is interpreted as uniquegood values (knowing the value of goodness, wanting to do good, and actually having a good life) which are embedded in oneself and are manifested in behavior. Character coherently emanates from the results of thought, heart, feeling and intention, as well as sports of a person or group of people (Mulyasa, 2014: 235). Character does not always reflect good behavior, because everyone has different perspectives and life habits. It takes a long time to build character and must be done on an ongoing basis. Character education must be sustainable and never ending in order to prepare a quality generation of the nation. Character education is about how to instill habits about the good things in life, so that someone has awareness, sensitivity, understanding, concern, and commitment to apply virtue in everyday life. Cultivating this habit is not only done in the school environment, the family and community circles also have a significant share. In community life, there are habits, customs, cultures and traditions that are different from one another. 
Traditions are habits and values that are passed from one generation to the next. Traditions usually contain a series of habitual elements and values that can be used as learning and knowledge. The values in a tradition will have a positive impact on society if they are properly implemented in people's lives. In the implementation of the tradition, of course there are special rituals or ceremonies that are usually carried out by the local community. From these habits an attitude or behavior is created which will increasingly form a character.

The phrase "the Javanese have lost their Javanese, or in Javanese it is called" wong jawa ora njawani "is an expression intended for Javanese people who have forgotten their own cultural traditions. According to Saddhono and Pramestuti, Javanese culture is a system that guides Javanese people in their behavior and attitudes. This is because Javanese culture has local wisdom that serves as a strong driver in the life of Javanese people (Saddhono \& Pramestuti, 2018: 15).

One form of Javanese culture that contains elements of local wisdom is the ritual tradition surrounding birth. Some of these ritual traditions include: the brokohan salvation ceremony or the ceremony after the baby is born, sepasaran (five days), selapanan (thirty five days), telunglapan (three months and fifteen days), mitoni (seven months), and ngetahuni (a year) ( Risdianawati \& Hanif, 2015: 63).

Ritual communication can be interpreted as the process of interpreting the message of a group of religious activities and the belief system it adheres to. In the process there is always the meaning of certain symbols which indicate the occurrence of the ritual communication process. In the process of ritual communication, there is often competition with formal religious understandings which then color the process. Ritual activity is one of the customs in culture. This activity is an activity that is often carried out by a certain community group or community as an effort to care or maintain what they have received or a request for safety, smoothness, convenience in all matters and so on.

A ritual or ceremony is a system or series of actions that are governed by custom or applicable laws in society that are related to various kinds of events that usually occur in the community concerned (Koentjaraningrat, 2002: 190). Ritual is a technique or method that makes a custom holy. Rituals create and maintain myths, social and religious customs. Rituals can be personal or group in nature, they can take the form of dance, drama and prayer. The ritual was first social then economic in nature and then developed into a sacred religious ritual. According to
Hamad (2006: 2-3) ritual communication is a close relationship with activities of sharing, participating, gathering, making friends from a community that has the same belief.The seven-month ritual (Tingkeban) is one of the traditions of the Javanese people, this ritual is also called mitoni, which comes from the word pitu, which means seven. This ceremony is held at seven months of gestation and at the first pregnancy. This ceremony means that education is not only after adulthood but since the seed is planted in the mother's womb.In this ceremony, the pregnant mother is bathed with Setaman flower water and accompanied by a prayer which aims to ask God to always be given grace and blessings so that the baby will be born safe and healthy.

Traditional ceremonies and ceremonies are one of the branches of Javanese culture. The existence of traditional procedures and ceremonies coupled with the union of physically and mentally asking for the grace of God Almighty, will foster a beauty that contains requests, reminders, teachings or guidance of the Javanese culture bearer to the Creator. The running of Javanese traditional ceremonies and ceremonies is a picture of the life journey of the Javanese, in which it is used as a reminder of the changing phases of Javanese human life. Accompanied by prayers and hopes that God will always provide salvation and pour out the gifts of love throughout his life.

The warnings in Javanese traditional ceremonies and ceremonies only lead to the desire for humans to remember "purwa, madya, lan wusananing dumadi" (beginning, middle, and end of life). About how the beginning of living life, the beginning of life, and the end of life later. All of which can be described in more depth by the term "sangkan paraning dumadi". Everything that comes from God will return to God.The procedure for the Javanese Life Travel Ceremony will be discussed using the term TA SAPTA JANTRANING URIP (Seven TA of life journeys) which consists of Titis, Titah, Tetes, Tarab, Tatap, Tutug, and Tutup. Through this research, it is hoped that readers will be able to know and apply good moral teachings that can be applied around Javanese traditional ceremonies and ceremonies along with the development of the times.

Starting from this background, the writer conducted a study entitled "Educational Value in Ta Sapta Jantraning Urip Sanggar Pasinaon Pambiwara Karaton Surakarta as Nation Character Builder".

\section{THEORETICAL BASIS}

The data obtained in this study also came from interviews with informants. The selected informants are those who are considered to have knowledge and 
experience in the fields of literature and culture and their learning. In this case, education activists are seen to be able to provide the needed information. The data validity test that is commonly carried out in qualitative research is the triangulation technique. Triangulation method and source triangulation is essentially a multimethodal approach that researchers take when collecting and analyzing data. Photographing a single phenomenon from different viewpoints allows a reliable level of truth to be obtained. Therefore, triangulation is an attempt to check the correctness of data or information obtained by researchers from different points of view by reducing as much as possible the bias that occurs during data collection and analysis. Denkin (in Rahardjo, 2010) defines triangulation as a combination or combination of various methods used to study interrelated phenomena from different viewpoints and perspectives. Until recently, the Denkin's concept was used by qualitative researchers in various fields. In this study, the research results were obtained through data collection, document/archive analysis, and interviews. The data were obtained through the analysis stage of the Ta Sapta Jantraning Urip archive belonging to Sanggar Pasinaon Pambiwara Karaton Surakarta Hadiningrat. Which is then collaborated with the data obtained through the interview stage. The two types of data can complement each other so as to produce the right conclusions. Therefore, the type of triangulation used is the triangulation of data sources.

This type of triangulation is considered in accordance with the research carried out, because the object of research is in the form of a drama script archive and the data sources used are documents and informants. The data analysis technique used in this study is a strand or flow analysis technique which includes three components, namely data reduction, data presentation, and drawing conclusions.

\section{RESEARCH METHODS}

Based on the problems posed, the form of this research is descriptive qualitative. This qualitative research is based on the research object obtained from the research data, namely Ta Sapta Jantraning Urip belonging to Sanggar Pasinaon Pambiwara Karaton Surakarta Hadiningrat. The research strategy used in this research is a single fixed strategy. The single fixed strategy is a qualitative descriptive research strategy whose research focus has been determined based on the aims and interests of the researcher before going into the field of study.The focus of this research is the value of education, and the relevance of Ta Sapta Jantraning Urip belonging to
Sanggar Pasinaon Pambiwara Karaton Surakarta Hadiningrat as forming the character of the nation. The data reviewed in this study are qualitative data. Sources of data in this study are sources / informants, events / activities, places / locations, and documents / archives.

The data collection technique used in this research is literature study technique. This technique, which is also called Library Research, is a data collection technique that is carried out by recording documents or archives related to the problem and the researcher's objectives. In addition, other techniques are used, namely document analysis techniques. Document analysis is carried out by careful examination of the document and its content to draw conclusions. Document analysis does not present a clear methodology but rather covers a variety of approaches to documentary sources. Documents can be defined as artifacts that have written text regardless of their physical appearance. Researchers can use a variety of documents including letters, official reports, administrative records, web pages, diaries and newspaper articles (Afifudin and Ahmad Saebani, 2009: 165). In this study, the document used was the Ta Sapta Jantraning Urip belonging to the Sanggar Pasinaon Pambiwara, Karaton Surakarta Hadiningrat.

\section{RESULTS AND DISCUSSION}

\section{Educative Value on Ta Sapta Jantraning Urip}

In Ta Sapta Jantraning Urip, there are several things related to educational values which contain moral messages and educational values that are useful for life. From the content analysis contained in Ta Sapta Jantraning Urip, the following educational values were obtained.

\section{a. Religious Values}

In Ta Sapta Jantraning Urip contains Islamic divine valuesthat are contained in Javanese traditional ceremonies. In every part of the Javanese traditional ceremony, it contains a divine value that is poured into the meaning of symbols such as offerings, traditional ceremonial equipment, Javanese make-up, clothing, all of which contain the meaning of prayer to God.

\section{b. The Value of Honesty}

The value of honesty contains good behavior, attitudes and words that can be trusted and able to convince someone. In Ta Sapta Jantraning Urip teaches people to say and behave honestly as it is and tell the events experienced as it is in accordance with the facts and reality that is happening. There are in the parental advice/advice to their children when they are getting married. 


\section{c. Value Curiosity}

The value of curiosity provides information that the community must be given concrete education to increase curiosity so that their knowledge and experience will increase. The value of curiosity also means an action that always tries to find out more deeply and extensively about what is being learned. As regarding the Javanese traditional ceremony in Ta Sapta Jantraning Urip it is important to be studied by the community

\section{d. Appreciate achievements}

The value of appreciating achievement is an act of always respecting and appreciating the services of someone who has made a positive contribution to life as well as an aspect of respecting others. In Ta Sapta Jantraning Urip also implies this. Respect for others is a sense of respect for achievement and being appreciative of others because of the good service and exemplary you get. In every series of traditional ceremonies everyone must work together to help each other.

\section{e. The Value of Hard Work}

The value of education that instills hard work is also the material discussed in the Ta Sapta Jantraning Urip. In Ta Sapta Jantraning Urip, it can be seen that to teach the value of hard work in societyby adapting customs.In holding a traditional ceremony it requires complicated and difficult preparation, so there is value in working hard to prepare and carry out the traditional ceremony procession.

\section{f. Independent Value}

Independence of thinking and acting is also conveyed in Ta Sapta Jantraning Urip which explains about independence and human nature in the world. This can be seen in the meaning of makeup, traditional clothing and teachings contained in a series of traditional ceremonies, every human being must be able to position himself and position himself as an individual creature and a creature of God. Humans are required to be patient when living life in the world because it is also stated that in the real world humans are racing against certain times and conditions. Therefore, humans must be able to be independent in thought and behavior in life.

\section{g. Creative Value}

Educational and creative values are always related because educational values also go hand in hand with human creativity values. The value of education will be more meaningful with the existence of human creativity in doing something or producing new ways or objects that can be used in applicative life.

\section{h.The Value of National Spirit}

One of the values contained in Ta Sapta Jantraning Urip is the spirit of nationality which puts forward the value of the homeland rather than personal interests.For a leader, the interests of the people in the realm of nationality are very important. Unity and unity are the main ideals that must be realized so as to create a high national spirit in social life based on noble religious values. This is reflected in the history of traditional marriages which were originally only worn by the king and the royal family. As a gift for the people, the king allowed his people to wear the king's clothes during traditional wedding ceremonies.

i. The Value of Love and Peace

The value of learning to love peace does not only come from direct speech in words, but can also be manifested in thoughts and actions. many want peace in social life.

\section{j. Friendly and Communicative Value}

Ta Sapta Jantraning Urip also provides educational value to be friendly with anyone and have good communication with others. Interaction and communication must be carried out in the community so that life is more lively and respects each other with good behavior, including in terms of language.

\section{k.Value of Social Care}

Every individual who lives in society must interact with others and carry out life activities that are in line with the valuesof social care.Ta Sapta Jantraning Urip also has social care valuesthat can be adapted in everyday life.We have to remind each other.A life that is enjoyable or miserable must be treated with maturity and must not be lulled by the realm of the false and temporary world. Therefore, ideally, we should care for each other. In addition, we should not simply forget the services of the people who have helped in our lives.

\section{TA SAPTA JANTRANING URIP}

\section{A. Titis}

The first Ta Sapta Jantraning Urip is Titis. Titis is a sign of the start of life when a man and a woman are united. After they have intercourse, then the water drops from a man who falls into the wiji (egg) in a woman, starting from where a woman becomes pregnant and will become a mother. As a form of Javanese gratitude to God Almighty, and a request that their pregnancy is always given safety without any obstacle, every odd month in a matter of Javanese months a Wilujengan is held, such as: one month salvation, three months salvation, and salvationi. Seven months (Mitoni). Selamatan or wilujengan which are 
commonly used by Javanese people in their lives is to use petangan lapan (count of eight / 35 days).

\section{B. Titah}

The second Ta Sapta Jantraning Urip is Titah. After nine months and ten days in the womb, the child is born into the world. With this a new human being is born who is still physically and mentally pure, like a sheet of white paper. The next action of the child depends on who educated him and what was taught to him, and what education he received. So that the child has a good personality and is always blessed with health, a wilujengan weton ceremony is performed, starting from the age of 35 days to 7 months of age.

\section{Tetes}

Drops or drops is a procedure that is carried out only for girls who are sawindu (8 years old). And the procedure for boys is the pagas purusa (supitan) procedure. At this time, there have been changes which can be seen in the form of the body, changes in attitude, character, and habits. The most important supitan traditional ceremony is to get rid of bad things in life and maintain health. Therefore, the supitan traditional ceremony is carried out using siraman and drinking herbal medicine, so that all the changes will be good and always be blessed with health.

D. Tarap

Tarap is a ceremonial procedure that is only carried out for women who have had their first month. This means that the girl has started to mature. The running of the traditional taraban ceremony is not much different from that of the traditional tetesan ceremony,which is drinking herbal medicine, siraman, and in this traditional ceremony there is a discourse which contains women's obligations from today onwards. Starting from the first period, pregnancy, child care, homework, and others. So a traditional ceremony of salvation was held in the hope that the child can live out his nature as an adult woman properly from today onwards.

E. Tatap

Starting from changes in life, all humans have things to like. Men began to like girls, women began to like boys. This is a journey of human life that cannot be avoided, because in human life, humans must continue their life by having offspring.Humans cannot be said to be perfect if they do not have children, because by having children there will be offspring who will continue and inherit the story of their life in the world.Having offspring can occur by marrying a boy and a girl. Therefore, in the stage of life it is called gaze.Starting from getting to know men and women, being talked about by parents, until marriage and living a household life until having children.

\section{F. Tutug}

When humans live in the world starting from birth, supitan, tarab procedures, marrying and having offspring, and have lived a lot of life in society, it can be called tutug or finished. Obligations as men and women have begun to be sidelined.Every night is only filled with worship to God. In order to get physical and spiritual salvation, and just waiting to die, if at any time it is called by God then it is ready with the deeds and worship it brings.

\section{G. Tutup}

Tutup, all obligations in the world have been done. Just waiting for nature in the grave means waiting for the afterlife. So wilujengan or salvation is held by the children and grandchildren so that the ancestors who have died are always protected by Allah in the grave, have their graves cleared, are guided to the right and bright path, and are given forgiveness for all mistakes in the world.Starting from one to the goal of this traditional ceremony, is a guide to human life according to Javanese culture. All of this does not contradict any religion which in principle teaches and contains teachings to always remember and worship God.

\section{CONCLUSIOS}

Based on the discussion of the Educative Value in Ta Sapta Jantraning Urip Sanggar Pasinaon Pambiwara Karaton Surakartaas a Nation Character Builder, it can be concluded that, the form of strengthening the value of character education in Ta Sapta Jantraning Urip Sanggar Pasinaon Pambiwara KaratonSurakarta for the community. The background of this research is the strengthening of the character education values associated with Ta Sapta Jantraning Urip Sanggar Pasinaon Pambiwara Karaton Surakarta. Strengthening educational valuesinclude moral values, social values, and cultural values.Moral values are obtained in the meaning of every Javanese traditional ceremony and all the offerings therein which have a teaching meaning to always be in the way of goodness. Social value is obtained from several examples in maintaining good relationships with others.The cultural values found are in terms of thinking and actions that have in common in society.

\section{REFERENCES}

[1] Afifudin \& Saebani A. 2009. Metodologi Penelitian Kualitatif. Bandung: Pustaka Setia. 
[2] Atkinson, P. 2010. "Making Opera Work: Bricolage and the Management of Dramaturgy" dalam Music and Arts in Action, Volume 3, Issue 1 (online). (http://musicandartsinaction.net/index.php/maia/article/view/ makingopera work diakses 9 April 2012 pukul 07:24).

[3] Boulton, M. 1983. The Anatomy of Drama. London, Boston, Melbourne, and Henley: Routledge \& Kegan Paul.

[4] Damhudi, D. 2011. Bahan Ajar Teori dan Pementasan Drama/Teater (online). (my.opera.com/imdedidamhudi/blog/2011/02/20/bahan-ajarteori-dan-pementasan-drama-teater, diakses 26 Februari 2012 pukul 07:26).

[5] Devilito, R., Wardani, N. E., \& Saddhono, K. (2017). Character Education Through Its Depiction of Life in The Novel Entitled Kerumunan Terakhir by Okky Madasari (Psychologycal Analysis of Literature). Lingua Didaktika: Jurnal Bahasa dan Pembelajaran Bahasa, 11(2), 185-194.

[6] Dewojati, C. 2010. Drama: Sejarah, Teori, dan Penerapannya. Yogyakarta:Gadjah Mada University Press.

[7] Douglas, J. (2016). Toward More Honest Description. The American Archivist, 79(1), 26-55.

[8] Endraswara, S. 2011. Metodologi Penelitian Sastra Epistemologi, Model, Teori, dan Aplikasi. Yogyakarta: Caps.

[9] Grosse, E. H., Glock, C. H., \& Neumann, W. P. (2017). Human factors in order picking: a content analysis of the literature. International Journal of Production Research, 55(5), 1260-1276.

[10] Hare, J. R. 2008. "Johnny Saldaña (2005). Ethnodrama: An Anthology of Reality Theatre (Crossroads In Qualitative Inquiry Series; Volume 5)", dalam Forum: Qualitative Social Research, Volume 9, No. 2, Art. 1 (online). (www.qualitative-research.net/fqs diakses 26 Februari 2012 pukul 07.39).

[11] Hasan, Z., \& Saladin. M. 1996. Pengantar Ilmu Sosial Dasar. Jakarta: Depdikbud.

[12] Hidayatullah, M. F. 2009. Guru Sejati: Membangun Insan Berkarakter Kuat \&Cerdas. Surakarta: Yuma Pustaka.

[13] Hind, K.R. and Saunders, G.W., 2013. A molecular phylogenetic study of the tribe Corallineae (Corallinales, Rhodophyta) with an assessment of genus-level taxonomic features and descriptions of novel genera. Journal of Pshycology, 49(1), pp.103-114.

[14] Ishak, A. H., \& Osman, M. R. (2016). A systematic literature review on Islamic values applied in quality management context. Journal of business ethics, 138(1), 103-112.

[15] Kinayati. 2006. "Pesona Karya Sastra dalam Pendidikan dan Pengajaran", dalam Jurnal Pendidikan dan Kebudayaan, No. 063 Tahun Ke-12 November 2006 (online). (isjd.pdii.lipi.go.id diakses pada 7 Maret 2012 pukul 21:32).

[16] Koentjaraningrat. 1992. Beberapa Pokok Antropologi Sosial. Jakarta: Dian Rakyat.

[17] Kosasih, E. 2003. Kompetensi Kebahasaan dan Kesusastraan Cermat Berbahasa Indonesia. Bandung: Yrama Widya.
[18] Mardiatmadja. 1986. Tantangan Dunia Pendidikan. Yogyakarta: Kanisius.

[19] Miles, M. B., \& Huberman, A. M. 1992. Analisis Data Kualitatif. Tjetjep RohendiRohidi (terj.). Jakarta: UI Press. 491 hal.

[20] Milawati, T. 2011. "Peningkatan Kemampuan Anak Memahami Drama dan Menulis Teks Drama Melalui Model Pembelajaran Somatis Auditori Visual Intelektual (Savi)" dalamPortal Jurnal Universitas Pendidikan Indonesia, Edisi Khusus No. 2, Agustus 2011 (online), hal. 70 - 78 (jurnal.upi.edu, diakses 5 Maret 2012 pukul 08:24).

[21] Moedjiono \& Dimyati, M. 1992. Strategi Belajar Mengajar. Jakarta: Depdikbud Dirjen Dikti.

[22] Mujianto, Y. 1988. Manik-manik Sastra II. Surakarta: BPK PBS FKIP UNS.

[23] Muntsani, M. 2009. Pesan Profetik dalam Naskah Drama Tinjauan Pedagogigs (online). (bismirindu.wordpress.com/2009/07/23/283/\#more-283 diakses 25 Februari 2012 pukul 15:01).

[24] Noor, R. M. 2011. Pendidikan Karakter Berbasis Sastra Solusi Pendidikan Moral yang Efektif. Yogyakarta: ArRuzz Media.

[25] Nugroho, R. A. 2007. Naskah Drama Monumen Karya Indra Tranggono (Sebuah Tinjauan Strukturalisme Genetik). Skripsi: Tidak dipublikasikan.

[26] Nurgiyantoro, B. 2005. Teori Pengkajian Fiksi. Yogyakarta: Gadjah Mada University Press.

[27] Pradopo, R. D. 1993. Pengkajian Puisi: Analisis Strata Norma dan Analisis Struktural dan Semiotik. Yogyakarta: Gadjah Mada University Press.

[28] _ 1994. Prinsip-Prinsip Karya Sastra. Yogyakarta: Gadjah Mada University Press.

[29] Pradotokusumo, P. S. 2005. Pengkajian Sastra. Jakarta: Gramedia Pustaka Utama.

[30] Rahardjo, M. 2010. Triangulasi dalam Penelitian Kualitatif (online).(http://mudjiarahardjo.com/profile/270.html?task= view, diakses7 Februari 2012).

[31] Rahmanto, B. 1988. Metode Pengajaran Sastra. Yogyakarta: Kanisius.

[32] Ratna, N. K. 2011. Teori, Metode, dan Teknik Penelitian Sastra. Yogyakarta: Pustaka Pelajar.

[33] Ristyowati. 2010. Kajian Struktural dan Nilai Pendidikan Cerita Rakyat Makam Joko Tarub dan Sapta Tirta Kabupaten Karanganyar. Skripsi: Tidak dipublikasikan.

[34] Saputri, N. R. 2008. Analisis Wacana Naskah Drama TVRI Yogyakarta yang Berjudul "Rerusuh" Karya M. Sugiarto. Skripsi: Tidak dipublikasikan.

[35] Semi, A. 1993. Anatomi Sastra. Padang: Angkasa Raya.

[36] Setiawan, D. 2009. Pengertian Pendidikan dan Pengajaran (online). (diskusipendidikan.forumotion.com, diakses 8 Maret 2012 pukul 17:16) Siswantoro. 2010. Metode Penelitian Sastra Analisis Struktur Puisi. Yogyakarta: Pustaka Pelajar.

[37] Soelaeman, M. 1987. Ilmu Budaya Dasar: Suatu Pengantar. Bandung: PT Eresco. 
International Journal of English Literature and Social Sciences, 5(4)

Jul-Aug 2020 /Available online: https://ijels.com/

[38] _ 1998. Ilmu Budaya Dasar: Suatu Pengantar. Bandung: PT Eresco.

[39] Somers, J. W. 2008. "Interactive Theatre: Drama as Social Intervention" dalam Music and Arts in Action, Volume1, Issue 1 (online).

(http://http://musicandartsinaction.net/index.php/maia/article /view/interact ivetheatre, diakses pada 21 Maret 2012 pukul 16:42). 